\title{
Biogenic catalysis in sulphide minerals' weathering processes and acid mine drainage genesis*
}

\author{
Mária Kušnierová ${ }^{,}$Mária Praščáková1凶 ${ }^{凶}$, Anna K. Nowak², Katarzyna Gorazda² and \\ Zbigniew Wzorek²
}

IInstitute of Geotechnics, Slovak Academy of Sciences, Kosice, Slovak Republic; ${ }^{2}$ Institute of Chemistry and Inorganic Technology, Cracow University of Technology, Kraków, Poland

\begin{abstract}
Bioleaching and biogenesis are the main outputs from a large group of environmental processes participating in the natural material cycle, used in raw materials processing. Bio-oxidation reactions are the main basis for bioleaching procedures, often participating in parallel leaching processes. During the leaching processes of polycomponent sulphide substrates, the factor of process selection also plays an important role, being in direct relation to the electric properties and galvanic effect occurring between the individual components of the leaching substrate. This work gives a summary of the results of a research focused on the possibilities of using biotechnological procedures for treatment of Slovak sulphide ores. The object of the research is extraction of valuable metals, undesirable admixtures and degradation of crystal lattice of sulphides for subsequent chemical leaching processing of precious metals. The results of experiments on the existence of biogenic processes in situ on waste dumps from exploitation containing residual sulphides are also presented. The processes result in acid mine drainage water generation. These waters are strongly mineralised (over $48 \mathrm{~g} / \mathrm{L}$ ) and of low $\mathrm{pH}$; that is why they are very caustic. The arsenic content $(2.558$ $\mathrm{mg} / \mathrm{L}$ ) in outflowing waters from old mines is high and over the limits set by the law.
\end{abstract}

Key words: sulphide minerals, weathering, acid mine drainage, biotransformation, Acidithiobacillus ferrooxidans

Received: 15 October, 2013; revised: 06 December, 2013; accepted: 11 December, 2013; available on-line: 22 January, 2014

\section{INTRODUCTION}

Krumbein dated the appearance of biogenic systems at the level of microorganisms during the Earth's development at approximately 1.1 billion years before man appeared (Krumbein, 1983). Microorganisms form the natural part of the biosphere, which is spread in a zone of approximately $40 \mathrm{~km}$ around the Earth, reaching $10 \mathrm{~km}$ under sea surface and $30 \mathrm{~km}$ into the stratosphere (Postgate, 1969). In this very dynamic space, microorganisms actively participate in, or initiate, processes of biogenesis, bioleaching, biocorrosion, biodegradation and bioaccumulation (Decker, 1986). The microorganisms' activity is the second most significant power after the Sun, securing the circle of life and elements on our planet. Essentially, almost all chemical changes are connected with the activity of living creatures. Any biological activity that causes a chemical change in one direction creates an activity in the opposite direction as well. As a result all elements submitted to chemical conversion go through periodical changes from organic into inorganic form and vice versa. The evidence for this is the most phenomenally observed circle of sulphur, nitrogen, carbon and many other elements in the biosphere (Postgate, 1969).

It is a matter of common observation that in the sulphide weathering process on the surface's anaerobic layer, zone extraction of $\mathrm{Cu}, \mathrm{Fe}, \mathrm{Pb}, \mathrm{Zn}, \mathrm{As}$ and $\mathrm{Sb}$, as well as other elements contained in these structures ( $\mathrm{Au}$ and Ag) occurs (Berry et al., 1983; Ramsdorf, 1969). As a consequence, there are also concentrated complexes of these metals, in the form of thiosulphate colloids and organic complexes that are transported into the layer parts below. If in this layer water containing sulphate-reducing bacteria such as Acidithiobacillus thioparus, Desulfovibrio, Desulfotomacullum are found, then the percolated sulphates are reduced and $\mathrm{H}_{2} \mathrm{~S}, \mathrm{HS}^{-}, \mathrm{S}^{2+}$ ions are created by the bacterial metabolic activity (Postgate, 1969; Nordstrom \& Southam, 1997; Luptakova et al., 2008). These ions, after contact with metals contained in acidic sulphuric waters, are precipitated as secondary sulphides such as pyrite, chalcosite, etc. So gradually a zone is being created of supergene beneficiation with sulphidic deposits (Berry et al., 1983; Ramsdorf, 1969). Part of the extracted metal elements' cations and $\mathrm{SO}_{4}{ }^{2+}$ anions become the component of mine drainage, as they are not transported into the deeper layer parts. Such occurrence causes an increase in mine drainage acidity, sometimes up to $\mathrm{pH}$ values less than 1.0, accelerating its mineralisation. The process also directly determines the genesis of acid mine drainage (AMD), which is toxic to the ambient biotope. Due to the sufficiently high metal concentration, AMD should be considered as a potential metal source.

From a vast group of environmental processes participating in the natural material circle, it is possible to use mainly the processes of bioleaching and biogenesis in raw materials processing and treatment (Lintnerova, 1996; Lintnerova et al., 1999; Sucha et al., 1997).

From the group of microorganisms hitherto known and described, a chemolithotrophic Acidithiobacillus ferrooxidans is the most significant for the bioleaching processes of sulphidic ores and wastes. It obtains the energy for its metabolic processes from oxidation (reduction) of inorganic substrates and possesses plasmids which code for resistance to toxic elements (Groudev \& Avakjan, 1989; Karavajko et al., 1988; Rawlings et al., 2003).

e-mail: prascak@saske.sk

*Presented at the 5th Central European Congress of Life Sciences "EUROBIOTECH 2013", Kraków, Poland.

Abbreviations: AMD, acid mine drainage 
Many authors have studied the processes of biological-chemical and chemical oxidation of sulphide minerals (Colmer \& Hinkle, 1947; Barret et al., 1996). The first consideration of these processes came in equation (1) by Natarjab and Torma (Torma, 1987):

where: $\mathrm{M}=\mathrm{Cu}, \mathrm{Fe}, \mathrm{Pb}, \mathrm{Zn}, \mathrm{As}, \mathrm{Sb}$, etc.

$$
\mathrm{MS}+2 \mathrm{O}_{2:} \stackrel{\mathrm{AT}}{\rightarrow} \mathrm{MSO}_{4}
$$

Bio-oxidation reactions are the main basis for bioleaching proceedings on the principle of direct or indirect oxidation. In practice, both procedures often participate in the leaching process in parallel (Tributsch, 2001). During the leaching process of the polycomponent sulphidic substrates, the factor of process selection also plays an important role - being in direct relation to the electrical properties and galvanic effect occurring between the individual components of the leaching substrate (Attia \& El-Zeky, 1990).

A. ferrooxidans bacteria play a role of the biocatalyst in these reactions, although its kinetics are influenced by many factors, such as size of the reaction surface, temperature, access to oxygen, content of nutrition components, $\mathrm{pH}$ values and presence of other inhibiting and activating factors of minor importance (Sucha et al., 1997; Rawlings et al., 2003; Barret et al., 1996; Torma 1987).

Lacy and coworkers (1970), following their study of the kinetics of chemical and biological-chemical oxidation of iron in the form of $\mathrm{FeSO}_{4}$ solution, discovered that under optimal conditions and through the activity of bacteria $A$. ferrooxidans, it is possible to reach a 500000 -fold increase in the speed of $\mathrm{Fe}^{2+}$ oxidation (Lacey \& Lawson, 1970). The biocatalytic influence of A. ferrooxidans bacteria was confirmed by the sulphidic mineral pyrite $\mathrm{FeS}_{2}$ oxidation. Experimentally determined increase in the oxidation speed was a factor of 1,000 (Groudev \& Avakjan, 1989). A. ferrooxidans bacteria are autochthonous and occur in the mine waters from sulphidic deposits, often together with Acidithiobacillus thiooxidans and Leptospirillum ferrooxidans bacteria that are components of the natural community "sulphuretum" and take part in the sulphur cycle in nature. It is possible to assume its catalytic influence "in situ" in the closed and flooded mining deposits of sulphidic minerals as well as wastes dumps with the residual content of sulphides (Luptakova et al., 2007; Kupka et al., 2007).

This information initiated interest in the possibility of comparing the consequences of environmental biogenic processes in the "in-situ"-environment of sulphide deposits with those under conditions of intensive laboratory bio-contamination of sulphides with $A$. ferrooxidans bacteria.

\section{MATERIALS AND METHODS}

Materials. Sulphide minerals and materials. All basic sulphides of the Slovak deposits were researched: chalcopyrite, tetrahedrite, arsenic pyrite, pyrite, antimonite, galena and sphalerite. Several forms of the sulphides examined, namely polished specimens, powder samples of separated minerals of $95 \%$ purity and grain size under $2 \mathrm{~mm}$, selective (Fe, $\mathrm{Cu}, \mathrm{Sb})$ and collective $(\mathrm{Pb}-\mathrm{Zn}, \mathrm{Fe}-\mathrm{As})$ flotation concentrates of the grain size under $0.07 \mathrm{~mm}$, were used in experiments.
Acidithiobacillus ferrooxidans bacteria. The microbial cultures of $A$. ferrooxidans were isolated from mining waters of Slovak sulphide deposits using classical methods and cultivating medium $9 \mathrm{~K}$ by Silverman and Lundgren (Silverman \& Lundgren, 1959; Buchanan \& Gibbons, 1974). The solution contained the following constituents: $\left(\mathrm{NH}_{4}\right)_{2} \mathrm{SO}_{4}-3.0 \mathrm{~g}, \mathrm{KCl}-0.1 \mathrm{~g}$, $\mathrm{K}_{2} \mathrm{HPO}_{4}-0.5 \mathrm{~g}, \mathrm{MgSO}_{4} 7 \mathrm{H}_{2} \mathrm{O}-0.5 \mathrm{~g}, \mathrm{Ca}\left(\mathrm{NO}_{3}\right)_{2}-$ $0.01 \mathrm{~g}$, distilled water $-700 \mathrm{ml}, \mathrm{H}_{2} \mathrm{SO}_{4}(10 \mathrm{~N})-1.0$ $\mathrm{ml}, \mathrm{FeSO}_{4} 7 \mathrm{H}_{2} \mathrm{O}(14.74 \%)-300 \mathrm{ml}, \mathrm{pH}$ 3.0-3.6.

Isolated bacteria were, in consequence, physiologically adapted to particular researched sulphides and then applied in experiments.

Leaching reagents. The cultivating medium $9 \mathrm{~K}$ part $A$ by Silverman and Lundgren was used in the experiments of biological-chemical and chemical oxidation. It possessed the following composition: $\left(\mathrm{NH}_{4}\right)_{2} \mathrm{SO}_{4}-3.0$ g, $\mathrm{KCl}-0.1 \mathrm{~g}, \mathrm{~K}_{2} \mathrm{HPO}_{4}-0.5 \mathrm{~g}, \mathrm{MgSO}_{4} 7 \mathrm{H}_{2} \mathrm{O}-0.5$ $\mathrm{g}, \mathrm{Ca}\left(\mathrm{NO}_{3}\right)_{2}-0.01 \mathrm{~g}$, distilled water $-700 \mathrm{ml}, \mathrm{H}_{2} \mathrm{SO}_{4}$ $(10 \mathrm{~N})-1.0 \mathrm{ml}$.

Methods. Biological-chemical and chemical oxidation examined samples. A leaching reagent part A of cultivating medium by Silverman and Lundgren of $\mathrm{pH} 1.5$ was used. In static experiments of oxidation, polished specimens were dipped in the leaching reagent for 50 days in a Petri plate.

Suspension of $15 \%$ density from the powder samples and leaching reagent was prepared in the dynamic experiments of the oxidation processes study. Suspensions were placed in glass banks and put on a shaker in the cultivation room for 10 to 50 days under the following conditions: temperature $30^{\circ} \mathrm{C}$, mixing amplitude $5 \mathrm{~mm}$, rotation speed $240 / \mathrm{min}$. During the experiments, analytical methods were applied to control extraction of the researched metals in the solution at one to three days' intervals.

All experiments were carried out in parallel:

- by the inoculated $A$. ferrooxidans bacteria, where biological-chemical oxidation occurred;

- in the abiotic conditions without inherence of bacteria, where only the process of chemical oxidation existed.

The methods of oxidation process evaluation. The processes of oxidation and bio-oxidation were monitored by atomic absorption spectrometry (AAS) using the AA30 Varian Spectrometer (Australia).

After the experiments, the transformation of solid phase of sulphides from the qualitative, morphologic and structural point of view was studied. In the case of polished specimens and separated grains of pure minerals, energy dispersive spectrometry (EDS) analysis was applied with the use of instruments; these consisted of a scanning electron microscope (SEM) BS 300 (Tesla, Czechoslovakia) and an X-ray micro-analyser EDAX 9100/60 (Philips, Holland). The samples were dried and coated with gold before the EDS analysis.

For phase changes of the researched materials, X-ray diffraction (XRD) analysis of insoluble remains of the leached sample was used. Analyser DRON 2.0 (Techsnabexport, Russia) with GUR-5 goniometry was employed.

The research was carried out partly under optimised conditions, in a discontinuous regime of leaching. The leaching agent was the liquid nutrient substrate according to Silverman and Lundgren $9 \mathrm{~K}$ part $\mathrm{A}$, with dispersed cells of thionic $A$. ferrooxidans bacteria, the concentration of which was circa $10^{7}$ per $\mathrm{ml}$. The initial value of $\mathrm{pH}$ was 1.5 , the temperature $30^{\circ} \mathrm{C}$ and the suspension density $15-20 \%$. In order to determine the qualitative changes of the leached substrates, the following methods were used: AAS, XRD analysis and EDS analysis. 
Table 1. The comparison of biological-chemical and abiotic chemical oxidation of arsenic pyrite in suspension

\begin{tabular}{|c|c|c|c|c|c|}
\hline \multirow{3}{*}{ Process } & \multicolumn{5}{|c|}{ Leaching time (days) } \\
\hline & 0 & 2 & 4 & 7 & 14 \\
\hline & \multicolumn{5}{|c|}{ The content of As in leachate (mg/L) } \\
\hline Biological-chemical + A. ferrooxidans & 0.013 & 0.222 & 1.180 & 2.270 & 2.558 \\
\hline Chemical (abiotic control) & * & * & 0.023 & 0.079 & 0.179 \\
\hline
\end{tabular}

*Below detection limits

Table 2. The data of As and $\mathrm{Cu}$ yield during a 12 day experiment

\begin{tabular}{lllll}
\hline & \multicolumn{2}{l}{ Yield of elements in the leachate (\%) } \\
\cline { 2 - 5 } Leaching time (day) & \multicolumn{2}{l}{ Bio-oxidation + A. ferrooxidans } & \multicolumn{2}{l}{$\begin{array}{l}\text { Chemical oxidation } \\
\text { (abiotic control) }\end{array}$} \\
\cline { 2 - 5 } & $\mathrm{As}$ & $\mathrm{Cu}$ & As & $\mathrm{Cu}$ \\
\hline 1 & 0.89 & 0.42 & 0.00 & 0.21 \\
\hline 5 & 9.56 & 1.00 & 0.12 & 0.21 \\
\hline 7 & 18.56 & 1.39 & 0.80 & 0.16 \\
\hline 12 & $79.63\left(76.35^{*}\right)$ & 4.02 & 5.09 & 0.29 \\
\hline
\end{tabular}

*The tentative yield without the galvanic effect

\section{RESULTS AND DISCUSSION}

The results of chemical, morphological and XRD analysis of the products of abiotic chemical oxidation in leaching agent $9 \mathrm{~K}$ part A confirmed that, in the samples researched, there was not any eminent change of phase composition. No morphological changes were noticed at the same time. The chemical analysis of the metals from the leachates during, and at the end of, the sulphide oxidation leaching process proved that values of metal concentration are fractional in the context of the content of researched metals in the solid phase.

Table 1 presents comparison of the biological-chemical and abiotic chemical oxidation of arsenic pyrite in suspension and uniquely confirmed bio-catalytic influence of $A$. ferrooxidans bacteria. The oxidation rate at 14 days' interval was fifteenfold higher $(0.182 \mathrm{mg} / \mathrm{L}$ per day) compared to the control abiotic experiment of

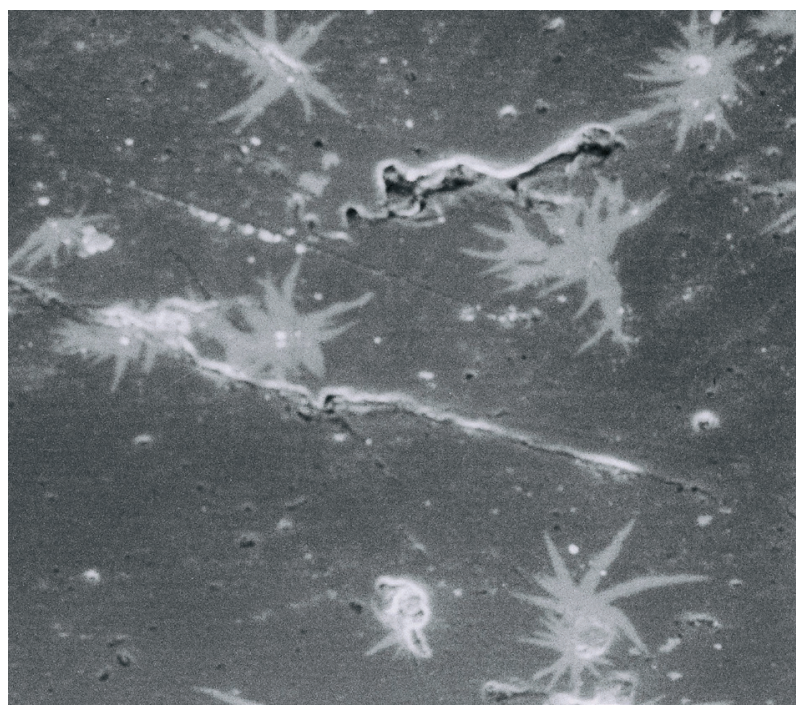

Figure 1. SEM micrographs of the selective creation of areas of etching near the surface defects of thetrahedrite after one day of bio-oxidation, $1000 \mathrm{x}$ magnification. chemical oxidation of arsenic pyrite $(0.012 \mathrm{mg} / \mathrm{L}$ per day).

Experiments carried out with the mixtures of two sulphidic minerals (arsenic pyrite and chalcopyrite) showed two significant factors, selectivity of the process and synergy of galvanic effect of both sulphides, respectively. Process section and the priority of arsenic pyrite biooxidation is evident from the yield data of $\mathrm{As}$ and $\mathrm{Cu}$ in the leachate during a 12-day experiment (Table 2).

Synergistic effect of galvanic activity on the selection and rate of arsenic pyrite oxidation can be anticipated only hypothetically on the basis of the difference of electrode potentials (Balaz, 2000). In the rating class of values, chalcopyrite is in the fourth position and arsenic pyrite in the ninth position. It is the basis of an assumption of an existence of the synergy effect. This also indicates the hypothetical difference between the mass yield of As in the leachate, when we consider the 15 fold increase in chemical oxidation rate after the catalytic influence of $A$. ferrooxidans bacteria (see Table 1 ).

During the period of 1-50 days of abiotic experiments of chemical oxidation, no changes in the morphology of the surface of the samples studied were noticed while

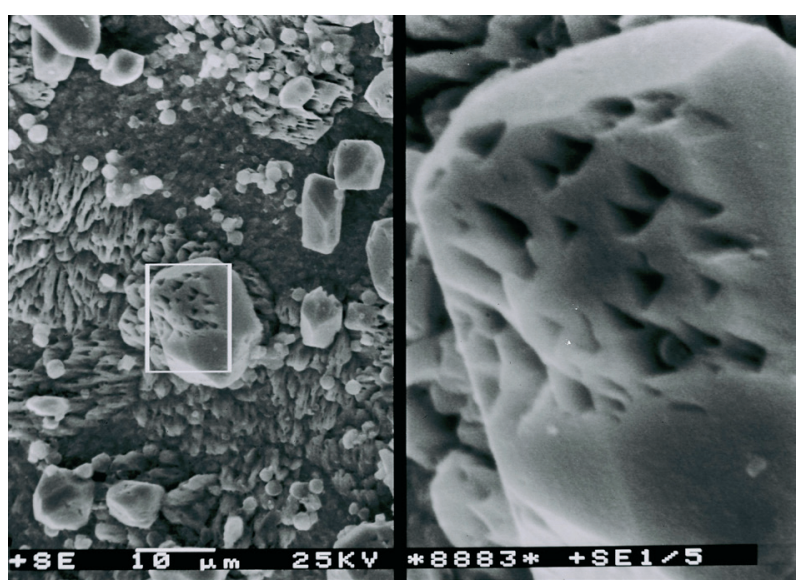

Figure 2. SEM micrographs of galenite morphological changes after 15 days of bio-oxidation. 
Table 3. Comparison of diffraction lines (X-ray difractograms) of pyrite before and after 10 days of biological-chemical oxidation by $A$. ferrooxidans bacteria

\begin{tabular}{llll}
\hline \multicolumn{2}{l}{ Measurement data $\mathrm{d}\left(\mathrm{A}^{0}\right)$} & & \\
\hline Original sample & After bio-oxidation & $\mathrm{hkl}$ & $\mathrm{l}$ \\
\hline 3.13 & 0.00 & 111 & 35 \\
\hline 2.71 & 2.71 & 200 & 85 \\
\hline 2.43 & 2.43 & 210 & 65 \\
\hline 2.21 & 2.21 & 211 & 50 \\
\hline 1.63 & 1.63 & 311 & 100 \\
\hline 1.56 & 1.56 & 222 & 14 \\
\hline
\end{tabular}

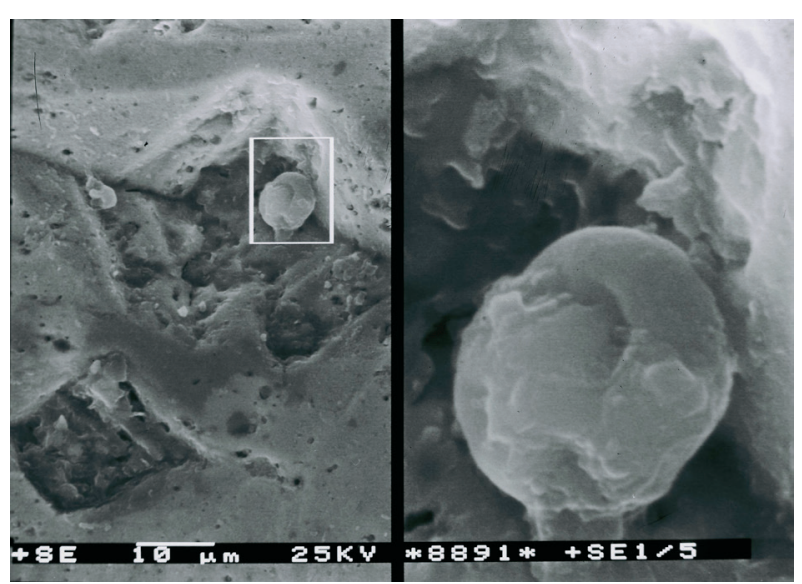

Figure 3. SEM micrographs of pyrite morphological changes after 30 days of bio-oxidation.

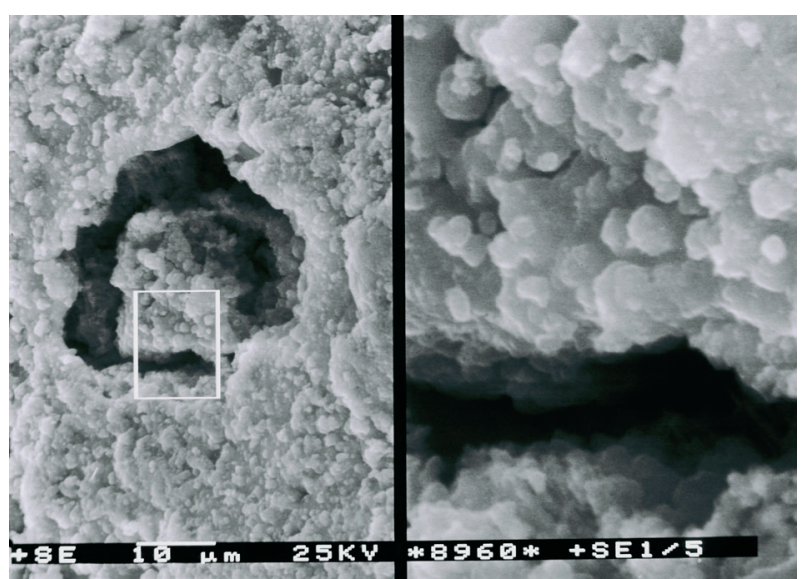

Figure 4. SEM micrographs of thetrahedrite morphological changes and creation of secondary mineral structure precipitates.

in the case of bio-oxidation with $A$. ferrooxidans bacteria, some changes gradually occurred. As we can see in Fig. 1, in the first stage of the process, after one day of bio-oxidation, areas of local etching were observed on the tetrahedrite surface.

The second stage, after 15 days of bio-oxidation, resulted in significant changes on the surface, in the form of selectively extracted caverns (Fig. 2) and deep breaks, especially on the contacts zones of sulphides (Fig. 3). In Table 3, the results of XRD analysis of pyrite after 10 days of bio-oxidation are summarised. These confirmed that the process of biological-chemical oxidation continued sequentially by the formation of etching cav-

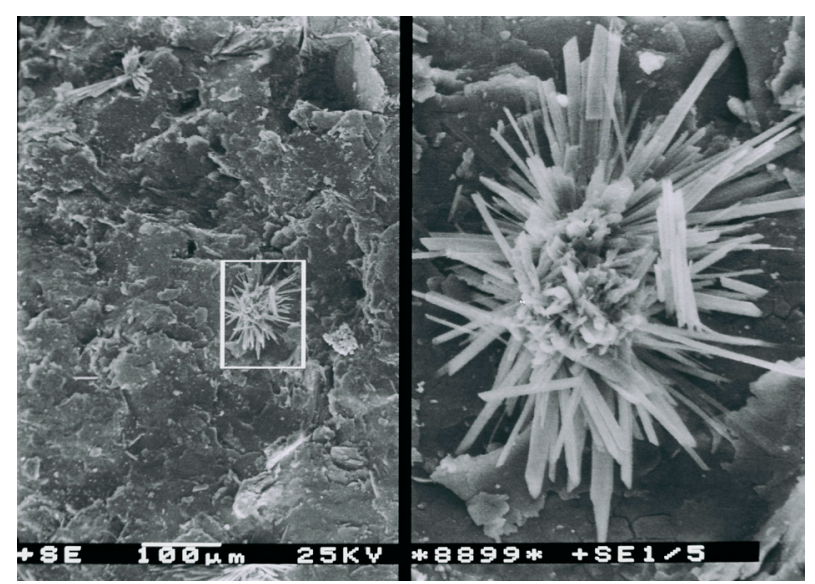

Figure 5. SEM micrographs of secondary gypsum created in the bio-oxidation process of arsenic pyrite with the crud of carbonates.

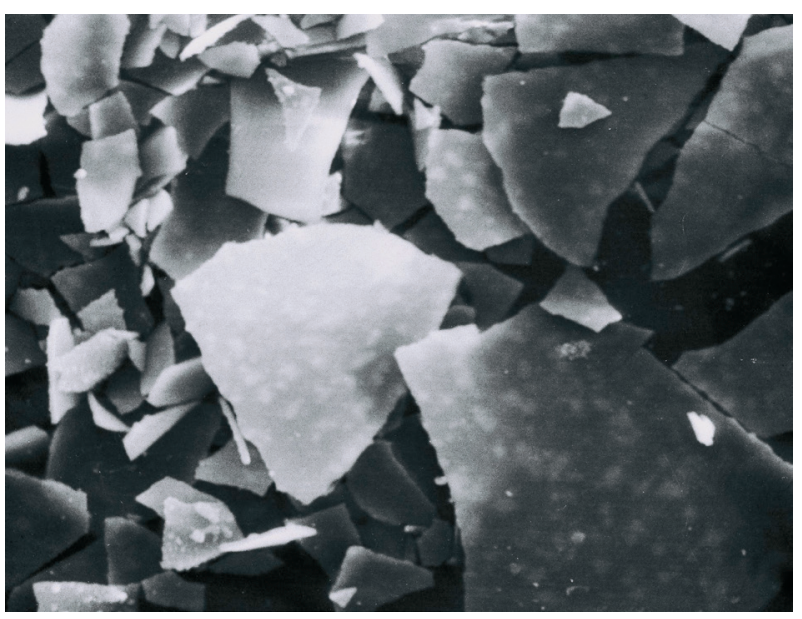

Figure 6. SEM micrograph of secondary jarosite particles created in the process of thetrahedrite bio-oxidation, $1520 \mathrm{x}$ magnification.

erns whose orientation was in direct relation to crystallographic orientation of the etched area in the mineral structure.

In the third stage, after 30 days of bio-oxidation, different precipitates of secondary structures appeared on the surface (Fig. 4). The process of bio-oxidation was completed after 50 days, as is confirmed by the presence of biological-chemically transformed structures of original sulphides (Figs. 5, 6).

The results of bio-transformation experiments under modelling conditions, of powder samples in the form of flotation concentrates, attest to the changes of original sulphides. The flotation concentrates also contained additives from surrounding minerals. In Table 4, results of phase composition of the examined samples after biooxidation are compared. Those results were compared with the phase composition of the weathering products that were published in the works focused on the exogenous weathering processes of the sulphidic deposits (Berry et al., 1983, Ramsdorf, 1969, Lintnerova et al., 1999, Pye \& Miller, 1990, Kusnierova et al., 1994).

During natural weathering processes, the sulphur is degraded sequentially from sulphides, while changing into sulphates, hydroxides, oxides or other oxide compounds depending on mineralogical and hydrogeological 
Table 4. Phase composition of samples after the bio-oxidation and the weathering products

\begin{tabular}{|c|c|c|}
\hline Original mineral & $\begin{array}{l}\text { Products of environmental } \\
\text { weathering process } \\
\text { (published data) }\end{array}$ & $\begin{array}{l}\text { Products of laboratory bio-oxidation process } \\
\text { (experimental results) }\end{array}$ \\
\hline \multirow[t]{2}{*}{ Pyrite $\mathrm{FeS}_{2}$} & $\begin{array}{l}\text { Jarosite } \mathrm{KFe}_{3}\left(\mathrm{SO}_{4}\right)_{2}(\mathrm{OH})_{6} \\
\text { Goethite } \mathrm{FeO}(\mathrm{OH}) \cdot \mathrm{nH}_{2} \mathrm{O}\end{array}$ & $\begin{array}{l}\text { Jarosite } \mathrm{KFe}_{3}\left(\mathrm{SO}_{4}\right)_{2}(\mathrm{OH})_{6} \\
\text { Goethite } \mathrm{FeO}(\mathrm{OH}) \cdot \mathrm{nH}_{2} \mathrm{O}\end{array}$ \\
\hline & Hydrogoethite $\mathrm{FeO}(\mathrm{OH}) \cdot 2 \mathrm{H}_{2} \mathrm{O}$ & Amarantite $\mathrm{FeSO}_{4}(\mathrm{OH}) \cdot 3 \mathrm{H}_{2} \mathrm{O}$ \\
\hline \multirow[b]{2}{*}{$\begin{array}{l}\text { Arsenic pyrite } \\
\text { FeAsS }\end{array}$} & Jarosite $\mathrm{KFe}_{3}\left(\mathrm{SO}_{4}\right)_{2}(\mathrm{OH})_{6}$ & Jarosite $\mathrm{KFe}_{3}\left(\mathrm{SO}_{4}\right)_{2}(\mathrm{OH})_{6}$ \\
\hline & $\begin{array}{l}\text { Pharmacosiderite } \mathrm{BaFe}_{4}\left[\left(\mathrm{AsO}_{4}\right)_{3}(\mathrm{OH})_{3}\right] \cdot 5 \mathrm{H}_{2} \mathrm{O} \\
\text { Scorodite } \mathrm{FeAsO} \mathrm{As}_{4} \cdot 2 \mathrm{H}_{2} \mathrm{O}\end{array}$ & $\begin{array}{l}\text { Sulphur } \mathrm{S} \\
\text { Arsenosiderite } \mathrm{Ca}_{2} \mathrm{Fe}_{3}\left(\mathrm{AsO}_{4}\right)_{3} \mathrm{O}_{2} \cdot(\mathrm{OH})_{3} \\
\text { Hydrojarosite } \mathrm{Fe}_{3}\left(\mathrm{SO}_{4}\right)_{2} \mathrm{OH}_{6} \cdot 2 \mathrm{H}_{2} \mathrm{O} \\
\text { Angelellite } \mathrm{Fe}_{4}\left(\mathrm{As}_{2} \mathrm{O}_{4}\right)_{2} \mathrm{O}_{3} \\
\text { Arsenolite } \mathrm{As}_{2} \mathrm{O}_{3} \\
\text { Butlerite } \mathrm{Fe}(\mathrm{OH})^{-\mathrm{SO}_{4}} \cdot 2 \mathrm{H}_{2} \mathrm{O}\end{array}$ \\
\hline \multirow[b]{2}{*}{$\begin{array}{l}\text { Tetrahedrite } \\
\mathrm{Cu}_{12}(\mathrm{As}, \mathrm{Sb})_{4} \mathrm{~S}_{13}\end{array}$} & $\begin{array}{l}\text { Chalcocite } \mathrm{Cu}_{2} \mathrm{~S} \\
\text { Malachite } \mathrm{Cu}_{2}\left(\mathrm{CO}_{3}\right)(\mathrm{OH})_{2}\end{array}$ & $\begin{array}{l}\text { Chalcocite } \mathrm{Cu}_{2} \mathrm{~S} \\
\text { Malachite } \mathrm{Cu}_{2}\left(\mathrm{CO}_{3}\right)(\mathrm{OH})_{2}\end{array}$ \\
\hline & $\begin{array}{l}\text { Cuprite } \mathrm{Cu}_{2} \mathrm{O} \\
\text { Covellite } \mathrm{CuS} \\
\text { Azurite } \mathrm{Cu}_{3}\left(\mathrm{CO}_{3}\right)_{2}(\mathrm{OH})_{2} \\
\text { Goethite } \mathrm{FeOOH} \cdot \mathrm{nH}_{2} \mathrm{O}\end{array}$ & $\begin{array}{l}\text { Stibnite } \mathrm{Sb}_{2} \mathrm{~S}_{3} \\
\text { Pharmacosiderite } \\
\mathrm{BaFe}_{4}\left(\mathrm{AsO}_{4}\right)_{3}(\mathrm{OH})_{3} \\
\text { Jarosite } \mathrm{KFe}_{3}\left(\mathrm{SO}_{4}\right)_{2} \mathrm{OH}_{6}\end{array}$ \\
\hline \multirow[b]{2}{*}{ Chalcopyrite $\mathrm{CuFeS}_{2}$} & Chalcanthite CuSO ${ }_{4} \cdot 5 \mathrm{H}_{2} \mathrm{O}$ & Chalcanthite CuSO ${ }_{4} \cdot 5 \mathrm{H}_{2} \mathrm{O}$ \\
\hline & $\begin{array}{l}\text { Bornite } \mathrm{Cu}_{2} \mathrm{FeS}_{4} \\
\text { Covellite } \mathrm{CuS} \\
\text { Azurite } \mathrm{Cu}_{3}\left(\mathrm{CO}_{3}\right)_{2}(\mathrm{OH})_{2} \\
\text { Cuprite } \mathrm{Cu}_{2} \mathrm{O}\end{array}$ & $\begin{array}{l}\text { Sulphur S } \\
\text { Malachite } \mathrm{Cu}_{2}\left(\mathrm{CO}_{3}\right)(\mathrm{OH})_{2}\end{array}$ \\
\hline \multirow{2}{*}{$\begin{array}{l}\text { Sphalerite } \\
\text { ZnS }\end{array}$} & $\begin{array}{l}\text { Smithsonite } \mathrm{Zn}\left(\mathrm{CO}_{3}\right) \\
\text { Willemite } \mathrm{Zn}_{2} \mathrm{SiO}_{4}\end{array}$ & $\begin{array}{l}\text { Smithsonite } \mathrm{Zn}\left(\mathrm{CO}_{3}\right) \\
\text { Willemite } \mathrm{Zn}_{2} \mathrm{SiO}_{4}\end{array}$ \\
\hline & $\begin{array}{l}\text { Hydrozincite } \mathrm{Zn}_{5}\left(\mathrm{CO}_{3}\right)_{2}(\mathrm{OH})_{6} \\
\text { Hemimorphite } \\
\mathrm{Zn}_{4}(\mathrm{OH})_{2}\left(\mathrm{Si}_{2} \mathrm{O}_{7}\right) \cdot \mathrm{H}_{2} \mathrm{O}\end{array}$ & $\begin{array}{l}\text { Zinc } \mathrm{Zn} \\
\text { Jarosite } \mathrm{KFe}_{3}\left(\mathrm{SO}_{4}\right)_{2} \mathrm{OH}_{6}\end{array}$ \\
\hline \multirow[b]{2}{*}{$\begin{array}{l}\text { Galenite } \\
\mathrm{PbS}\end{array}$} & $\begin{array}{l}\text { Anglesite } \mathrm{Pb}\left(\mathrm{SO}_{4}\right) \\
\text { Cerussite } \mathrm{Pb}\left(\mathrm{CO}_{3}\right)\end{array}$ & $\begin{array}{l}\text { Anglesite } \mathrm{Pb}\left(\mathrm{SO}_{4}\right) \\
\text { Cerussite } \mathrm{Pb}\left(\mathrm{CO}_{3}\right)\end{array}$ \\
\hline & $\begin{array}{l}\text { Crocoite } \mathrm{PbCrO}_{4} \\
\text { Wulfenite } \mathrm{PbMOO}_{4} \\
\text { Pyromorphite } \mathrm{Pb}_{5}\left(\mathrm{PO}_{4}\right)_{3} \mathrm{Cl}\end{array}$ & $\begin{array}{l}\text { Leadhillite } \mathrm{Pb}_{4}\left(\mathrm{SO}_{4}\right)\left(\mathrm{CO}_{3}\right)_{2}(\mathrm{OH})_{2} \\
\text { Minium } \mathrm{Pb}_{3} \mathrm{O}_{4} \\
\text { Plumbojarosite } \mathrm{PbFe}_{6}\left(\mathrm{SO}_{4}\right)_{4}(\mathrm{OH})_{12}\end{array}$ \\
\hline \multirow[b]{2}{*}{$\begin{array}{l}\text { Stibnite } \\
\mathrm{Sb}_{2} \mathrm{~S}_{3}\end{array}$} & $\begin{array}{l}\text { Kermesite } \mathrm{Sb}_{2} \mathrm{~S}_{2} \mathrm{O} \\
\text { Valentite } \mathrm{Sb}_{2} \mathrm{O}_{3}\end{array}$ & $\begin{array}{l}\text { Kermesite } \mathrm{Sb}_{2} \mathrm{~S}_{2} \mathrm{O} \\
\text { Valentite } \mathrm{Sb}_{2} \mathrm{O}_{3}\end{array}$ \\
\hline & $\begin{array}{l}\text { Senarmontite } \mathrm{Sb}_{2} \mathrm{O}_{3} \\
\text { Servantite } \mathrm{Sb}_{2} \mathrm{O}_{4}\end{array}$ & $\begin{array}{l}\text { Sulphur } \mathrm{S} \\
\text { Antimony } \mathrm{Sb} \\
\text { Onoratoite } \mathrm{Sb}_{8} \mathrm{O}_{11} \mathrm{Cl}_{2}\end{array}$ \\
\hline
\end{tabular}

conditions in the environment. As it is obvious from the results in Table 3, the compounds that appeared in the process of experimental bio-oxidation are identical to the products of natural weathering processes. These are mainly jarosite, malachite, chalcocite, smithsonite, anglesite, cerussite, kermesite and valentite structures. The results of tetrahedrite bio-transformation are interesting, because in addition to oxidation products, secondary sulphides of stephanite, antimonite and chalcocite are also formed as the result of subsequent reduction processes in nature that are typical of the area of supergene enrichment zones of sulphidic deposits.

The evidence that, in addition to bio-oxidation, reduction procedures also take place in the researched system, is the identification of elementary sulphur, antimonide and zinc in the laboratory bacterial leachate. The formation of secondary structures under research conditions was influenced by ion composition of bio-extraction solutions, which is closely connected with the mineralogical composition of basic substrate. For example the formation and crystallisation of gypsum (see Fig. 5) occurred as a result of bio-transformation of arsenic pyrite in contact with a carbonic-bearing rock. This is also proved by the structures of stephanite, chalcocite and antimonite in the bio-transformation of tetrahedrite with admixture of other sulphides.

Results acknowledge conformity of some products with the oxidation of sulphides described by geologists, which are mainly presented as chemical and physicalchemical processes and do not deliberately influence autochthonous microflora. The direct detection of biogenic catalysis in exogenous weathering processes of sulphides takes also place during acid mine drainage (AMD) generation. The intensity of these processes is different on each deposit and the reason why it is so was not observed until now. The fact is that some natural formations of closed deposits and dumps of wastes after mining activity can be included in the category of natural geo-bioreactors.

Some of them, e.g. waste dump from quartz exploitation in Sobov (Slovakia) with residual content of sulphides, works nowadays as natural geo-bioreactor with a strong devastating impact on the biotope of the dump, as the percolating waters are very caustic; their $\mathrm{pH}$ is within 1 to 2.6, containing thionic bacteria that catalyse the sulphides' oxidation. The presence of $A$. ferrooxidans 
Table 5. Basic characteristics of the AMD from the Pech shaft of the Smolnik (Slovakia) deposit isolated from different depths

\begin{tabular}{lcccc}
\hline $\begin{array}{l}\text { Depth AMD was isolated } \\
\text { from }(\mathrm{m})\end{array}$ & Mineralization $(\mathrm{mg} / \mathrm{L})$ & $\mathrm{pH}$ & $\begin{array}{l}\text { Sulphate content } \\
(\mathrm{mg} / \mathrm{L})\end{array}$ & Presence of bacteria \\
\hline 300 & 48596 & 3.51 & 37380 & $\begin{array}{l}\text { Acidithiobacillus ferrooxidans } \\
\text { Leptospirillum ferrooxidans }\end{array}$ \\
\hdashline 15 & 7625 & 3.46 & 5804 & $\begin{array}{l}\text { Acidithiobacillus ferrooxidans } \\
\text { Leptospirillum ferrooxidans }\end{array}$ \\
\hline
\end{tabular}

cells in the concentration of $10^{8}$ per $\mathrm{ml}$, together with the Acidithiobacillus thiooxidans and Leptospirillum ferrooxidans cell was observed in the waters percolating in the area of the dump.

The next example is the Smolnik (Slovakia) deposit where $\mathrm{Au}, \mathrm{Ag}$ and later (in the $14^{\text {th }}$ century) $\mathrm{Fe}-\mathrm{Cu}$ ores were also deposited. In 1992, this deposit was flooded. Now it is a location we are interested in for monitoring studies and modelling of geochemical progress of AMD quality. The basic data on the AMD that flowed out from the Pech shaft are shown in Table 5.

By reason of AMD effusion into the environment, this is extremely devastating. Evidence is the fish extinction in the streams, destruction of natural fauna and flora in the polluted area and final erosion.

\section{CONCLUSIONS}

On the basis of the above-mentioned results, it could be stated that a study of the biogenic processes under appropriately modelled conditions of laboratory experiments enables prognosis for development of long-term biogenic processes in real waste dumps formed after exploitation and processing of sulphides. The methodical apparatus developed here can clarify, in a short time, the initial elements of biogenic catalysis of environmental processes and, in some cases, also help to solve environmental problems using suitable tools to influence the present state.

The study of these processes, from the point of view of basic research, has led to clarification of some aspects of biological-chemical oxidation and the consequences in the different systems: thionic bacteria Acidithiobacillus ferrooxidans, Thiobacillus thiooxidans and Leptospirillum ferrooxidans combined with sulphides, mixture of sulphides and sulphide ore.

On the basis of the study of biotransformation processes with individual sulphides and their mixtures, it is possible to state that:

- the process of biological-chemical oxidation was predominantly activated in the area of macro-defects in the structure and contact zones of individual grains or contact areas with accompanying mineral components;

- the process of biological-chemical oxidation continued sequentially with the formation of etching caverns whose orientation was in direct relation to crystallographic orientation of the etched area in the mineral structure;

- as a result of biological-chemical oxidation of the researched sulphides, the gradual degradation of their structures proceeded also under conditions of a discontinuous process; and in the end, a complete degradation and sequential formation of secondary compounds on the basis of oxides, hydroxides, sulphates and basic elements, mainly sulphur, occurred.

There exists a real possibility for utilisation of these results in different areas and their comparison with the published data of geochemical studies of weathering processes. Above all, in the sphere of geochemical evolution of AMD and percolation water prognosis, there are high environmental risks in the areas of old mining loads. The results of geochemical modelling enable preventive prognosis of possible risk and the development of appropriate way to remediate this area. In the case of extremely high concentrations of acid mine drainage, it can be used as a potential unconventional raw material source (Slesarova et al., 2007).

From the point of view of treatment technologies, the results achieved can allow wider recourse to biotechnological processes, mainly in the treatment and processing of some sulphides as well as tetrahedrite and gold-bearing arsenic pyrite. On the basis of these results, the application of biological-chemical leaching methods permits the elimination of classical pyrometallurgical processes that produce toxic exhalants (Kusnierova, 1999) and utilization of cyanides in the process of selective flotation of gold-bearing ores of arsenic pyrite.

The results of the study on environmental biogenic processes in selected waste dumps after mining, processing and metallurgic activities confirmed the assumptions that the researched waste deposits in the natural environment are not stable. After a certain time interval, the biogenic processes not cease.

\section{Acknowledgements}

This work was supported by the Operational Programme Research and Development through the project: Centre of Excellence for Integrated Research of the Earth's Geosphere (ITMS: 26220120064), which is co-financed through the European Regional Development Fund, SGA project No. VEGA-2/0086/10 and within the SRDA project No. APVV-0252-10.

\section{REFERENCES}

Attia YA, El-Zeky M (1990) Effect of galvanic interactions of sulfides. Int J Mineral Process 30: 99-111.

Balaz P (2000) Extractive Metallurgy of Activated Minerals. Elsevier Science B.V., Amsterdam.

Barret J, Hughes MN, Karavajko GI, Spencer PA (1996) Metal extraction by bacterial oxidation of minerals. Ellis Horwood, New York, London, Toronto, Sydney, Tokyo, Singapore.

Berry L, Mason B, Dietrich R (1983) Mineralogy. Freeman San Francisco.

Buchanan RE, Gibbons NE (1974) Bergy's Manual of Determinative Bacteriology. $8^{\text {th }}$ edn. Williams and Wilkins, Baltimore, Maryland.

Colmer AR, Hinkle ME (1947) The role of microorganisms in acid mine drainage. A preliminary report. Science 106: 253.

Decker RF (1986) Biotechnology/Materials: The growing Interface. Metallurgical Transactions A 17/1: 5-30.

Groudev S, Avakjan ZA (1989) Biotechnology of Metalls. 6KNT, Moscow.

Lintnerova O (1996) Mineralogy of Fe-orche deposits formed form acid mine water in the Smolnik mine (Slovakia). Geologica Carphatica - Clays 5: 55-63.

Lintnerova O, Sucha V, Stresko V (1999) Mineralogy and geochemistry of acid mine Fe precipitates from the main Slovak mining regions. Geologica Carphatica 50: 395-404.

Luptakova A, Macingova E, Ubaldini S, Jencarova J (2008) Bioleaching of antimony minerals by bacteria Acidithiobacillus ferrooxidans and Desulfovibrio desulfuricans. Chemicke Listy 102: 409-411. 
Karavajko GI, Rossi G, Agathe AD, Groudev SN, Avakyan ZA (1988) Biotechnology of metals. Centre for international project GKNT, Moscow.

Krumbein WE (1983) Microbial Geochemistry, pp 1-4. Blackwell Scientific Publications.

Kupka D, Rzhepishevska OI, Dopson M, Lindstorm EB, Karnachuk $\mathrm{OV}$, Tuovinen $\mathrm{OH}$ (2007) Bacterial oxidation of ferrous iron at low temperatures. Biotechnology and Bioengineering 97/6: 1470-1478.

Kusnierova M, Andras P, Krizani I (1994) The influence of the chemical composition and the crystal structure of arsenopyrite and pyrite on the process of bacterial oxidation. Mineralia Slovaca 26: 272-276.

Kusnierova M (1999) Biogenic processes in the processing of gold-bearing sulphides. Mineralia Slovaca 31: 373-378.

Lacey DT, Lawson F (1970) Kinetics of the liquid phase oxidation of acid ferrous sulfate by the bacterium Thiobacillus ferrooxidans. Biotechnology and Bioengineering 12/1: 29.

Luptakova A, Macingova E, Slesarova A, Ubaldini S, Abbruzzsese C (2007) Solubilization and immobilization of toxic metals by bacteria. In Proceedings of the IMWA symposium: Water in Mining Enviroments, Cidu R Frau F, eds, MAKOEDIZIONI pp 437-439.

Nordstrom DK, Southam G (1997) Geomicrobiology of sulfide mineral oxidation. Reviews in Mineralogy 361-390.

Postgate J (1969) Microbes and man. Cambridge University Press, Penguin books, Ltd.
Pye K, Miller JA (1990) Chemical and biochemical weathering of pyritic mudrocks in a shale embankment. Quarterly Journal of Engineering Geology 23: 365-381.

Ramsdorf P (1969) The ore minerals \& their intergrowths. Pergamon Press, Oxford.

Rawlings DE, Dew D, du Plessis C (2003) Biomineralization of metalcontaining ores and concentrates. Trends Biotechnol 21: 38-44.

Silverman MP, Lundgren DG (1959) Studies on the chemoautotrophic iron bacterium Ferrobacillus ferrooxidans an improved medium and a harvesting procedure for securing high cell yields. J Bacteriol 77: 642-647.

Slesarova A, Zeman J, Kusnierova M (2007) Geochemical characteristics of acid mine drainage at the Smolnik deposit (Slovak Republic). In Proceedings of the IMWA symposium: Water in Mining Enviroments, Cidu R Frau F, eds, MAKOEDIZIONI, pp 467-471.

Sucha V, Kraus I, Zlocha M, Stresko V, Gasparovicova M, Lintnerova O, Uhlik P (1997) Mineralia Slovaca 29: 407-416.

Torma AE (1987) Impact of biotechnology on metals extractions. Mineral Processing and Extractive Metallurgy Review 2: 289-330.

Tributsch H (2001) Direct vs. indirect bioleaching. Hydrometallurgy 59: $177-185$. 